\title{
NA POGRANICZU REALIZMU: KOBIETA I KOBIECOŚĆ W TEATRZE JAPOŃSKIM
}

\author{
ESTERA ŻEROMSKA \\ (Uniwersytet im. Adama Mickiewicza w Poznaniu)
}

Słowa kluczowe: nowoczesny teatr japoński - shinpa - shingeki - realizm - Kawakami Otojirō Osanai Kaoru - Sada Yakko

Key words: modern Japanese theatre - shinpa - shingeki - realism - Kawakami Otojirō -

Osanai Kaoru - Sada Yakko

\begin{abstract}
Abstrakt: Estera Żeromska. NA POGRANICZU REALIZMU: KOBIETA I KOBIECOŚĆ W TEATRZE JAPOŃSKIM. PORÓWNANIA 18, 2016. T. XVIII. S. 239-255. ISSN 1733-165X. Kiedy w drugiej połowie XIX wieku w Japonii zaczął się wyłaniać nowoczesny teatr w stylu europejskim (shinpa, shingeki), jego inicjatorzy i entuzjaści nie tylko nie mieli szansy na odnalezienie $\mathrm{w}$ rodzimej tradycji widowiskowej jakiegokolwiek punktu odniesienia, ale nawet niezbyt dobrze wiedzieli, jaki jest ten teatr zachodni, który chcieli naśladować. Nie mogli wiedzieć, skoro od połowy VI wieku1 Japończycy pozostawali w kręgu silnego oddziaływania cywilizacji chińskiej, a przez ponad dwa i pół stulecia (1600-1868) żyli w całkowitej izolacji od świata i trwali w przekonaniu, że widowisko sceniczne jest domeną wyłącznie męską. Pionierzy nowego teatru (Kawakami Otojirō, Osanaia Kaoru, Ichikawę Sadanji II, Shimamura Hōgetsu) tworzyli go zatem od podstaw, początkowo niemal całkowicie intuicyjnie i nieporadnie, ale z wielką pasją i determinacją, wbrew wszelkim przeciwnościom. Utorowali drogę nowemu japońskiemu dramatowi, reżyserii i aktorstwu. Sprawiając, że na scenie pojawiły się pierwsze zawodowe aktorki (Chitose Beiha, Hanako, Sada Yakko, Matsui Sumako), nacechowali teatr japoński - obcym tradycji nō, kyōgen czy kabuki - realizmem.
\end{abstract}

Abstract: Estera Żeromska. ON THE BORDER OF REALISM: WOMAN AND WOMANHOOD
IN THE JAPANESE THEATRE. COMPARISONS 18, 2016. Vol. XVIII. P. 239-255. ISSN 1733-165X.
The European style modern theatre (shimpa, shingeki) started to emerge in Japan in the second
half of the nineteenth century. However, its initiators not only could not draw on the Japanese
performing tradition, they also had no specific knowledge of how the western theatre should

${ }^{1}$ Podaje się dwie przypuszczalne daty wprowadzenia buddyzmu do Japonii: 538 lub 552. 
look like. It was impossible for the Japanese to gain such familiarity with this subject: from the second half of the sixth century ${ }^{2}$ onward Japan remained under a strong influence of the Chinese civilization and for over two hundred and fifty years (1600-1868) was isolated from the rest of the world. For these reasons, the Japanese lingered in a world of conviction that the performing arts were only the men's domain. The Pionieers (Kawakami Otojirō, Osanai Kaoru, Ichikawa Sadanji II, Shimamura Hōgetsu) were creating the new performing art from the very beginning, relying mainly on intuition, somewhat awkwardly, but with passion and determination against different obstacles. They opened the door to the new Japanese drama, directing, acting; they welcomed to the stage the first professional actresses (Chitose Beiha, Hanako, Sada Yakko, Matsui Sumako) and left on the Japanese theatre nō, kyōgen or kabuki a foreign mark of realism.

Kiedy w drugiej połowie XIX wieku w Japonii zaczął się wyłaniać nowoczesny teatr $\mathrm{w}$ stylu europejskim (shinpa, shingeki), jego inicjatorzy i entuzjaści nie tylko nie mieli szansy na odnalezienie $\mathrm{w}$ rodzimej tradycji widowiskowej jakiegokolwiek punktu odniesienia, ale nawet niezbyt dobrze wiedzieli, jaki jest ten teatr zachodni, który chcieli naśladować. Nie mogli wiedzieć, skoro od połowy VI wie$\mathrm{ku}^{3}$ Japończycy pozostawali w kręgu silnego oddziaływania cywilizacji chińskiej, a przez ponad dwa i pół stulecia (1639-1868) żyli w całkowitej izolacji od świata i trwali w przekonaniu, że widowisko sceniczne jest domeną wyłącznie męską. Pionierzy nowego teatru tworzyli go zatem od podstaw, początkowo niemal całkowicie intuicyjnie i nieporadnie, ale $\mathrm{z}$ wielką pasją i determinacją, wbrew wszelkim przeciwnościom. Utorowali drogę nowemu japońskiemu dramatowi, reżyserii i aktorstwu. Sprawiając, że na scenie pojawiły pierwsze zawodowe aktorki, nacechowali teatr japoński realizmem, który jest obcy tradycji nō, kyōgen czy kabuki ${ }^{4}$.

\section{Kobieta i kobiecość w klasycznym teatrze japońskim (do połowy XIX wieku)}

Początki japońskiego aktorstwa kobiecego, podobnie jak początki całej japońskiej tradycji widowiskowej, sięgają czasów mitologicznych. Tego rodzaju ślady

\footnotetext{
2 Presumably Buddhism was officially introduced in Japan in 538 or 552.

3 Podaje się dwie przypuszczalne daty wprowadzenia buddyzmu do Japonii: 538 lub 552.

4 Pierwszym gatunkiem teatru japońskiego jest teatr $n \bar{o}$, który powstał na przełomie XIV i XV wieku, czyli niemal w tym samym czasie, co farsa kyōgen. Na początku XVII wieku wyłonił się jeszcze mieszczański teatr kabuki oraz teatr lalkowy ningyō jōruri (profesjonalna odmiana: bunraku). We wszystkich tych gatunkach teatru występują wyłącznie mężczyźni. Szerzej na temat klasycznego teatru japońskiego zob. m.in.: E. Żeromska. Japoński teatr klasyczny. Korzenie i metamorfozy. T. I Nō, kyōgen, t. II Kabuki, bunraku. Warszawa: Wydawnictwo TRIO, 2010; J. M. Rodowicz, Boski dwumian. Wrocław: Instytut im. Jerzego Grotowskiego, 2009.
} 
odnajdujemy w uwiecznionym w kronikach Kojiki (712) 5 i Nihongi (720)6 słynnym micie o zamknięciu się w pieczarze bogini słońca Amaterasu, a zwłaszcza w jego fragmencie dotyczącym - wykonanego na ustawionej przed tą jaskinią beczce - orgiastycznego, nazwanego kagura ${ }^{7}$, tańca bogini o frywolnym usposobieniu, Ama-no Uzume, określanej mianem protoplastki sakralnego widowiska kagura, a zarazem pierwszej japońskiej artystki scenicznej (tancerki, aktorki). Była nią zatem bogini, która - można powiedzieć - zaprezentowała kobiece widowisko (josei geinō).

W rzeczywistości w Japonii od zarania obrzędy sintoistyczne, a od połowy VI wieku również buddyjskie ${ }^{8}$, celebrowali jedynie mężczyźni, dlatego nikogo nie dziwiła ich wyłączna obecność we wszystkich widowiskach (w tym w teatrze: nō, kyōgen, kabuki, ningyō jōruri), które powstawały i rozwijały się w korelacji ze sferą sacrum. Do sfery tej, z powodu obowiązujących tabu, kobiety nie były dopuszczane. W oficjalnym nurcie życia pełniły one głównie rolę opiekunek ogniska domowego. Jako artystki mogły się więc rozwijać jedynie na pograniczu sztuki i nierządu. Mimo to tworzono dramaty o kobietach, z których wiele uczyniono nawet tytułowymi bohaterkami. Odgrywający je na scenie mężczyźni zostali zatem zmuszeni do tego, aby, używając właściwych dla danego gatunku technik gry, tworzyć złudzenie kobiecości. W tym celu aktor nō ukrywa własną twarz za odpowiednią maską, a ciało - pod obszernym, tuszującym atrybuty płci kostiumem. Niezależnie od wieku, statusu społecznego czy wykształcenia przedstawianej postaci sprawia on wrażenie naturalności - skonwencjonalizowanej, stylizowanej, odrealnionej z powodu męskości, ale naturalności, zawsze odzwierciedlającej istotę rzeczy ${ }^{9}$. Dla odmiany widz kyōgen - gatunku będącego komediowym dopełnieniem poważnego, refleksyjnego nō - bez trudu może dostrzec, że zarówno młoda dziewczyna, jak i staruszka jest prezentowana przez mężczyznę w sposób całkowicie symboliczny. Aktor kyōgen nie stara się być kobiecy. Występując bez maski, z twarzą nie-

${ }^{5}$ Kojiki - najstarszy zabytek piśmiennictwa japońskiego. Wydanie polskie: Kojiki czyli Księga dawnych wydarzeń. Tłum. W. Kotański. Warszawa, 1986. Por. artykuł M. Wesołowskiej pt. Muzyka w Kojiki w niniejszym tomie (s. 257-281).

${ }^{6}$ Nihongi (właśc. Nihonshoki, Kroniki japońskie) - drugie po Kojiki, składające się z trzydziestu zwojów japońskie dzieło historiograficzne. Zob. J. Tubielewicz, Kultura Japonii. Słownik. Warszawa: WSiP, 1996. S. 224-225.

${ }^{7}$ Kagura (dosł. muzyka/rozrywka bogów, muzyka/rozrywka dla bogów) - obrzędowe widowisko taneczno-muzyczne wywodzące się z prahistorycznych rytuałów sintoistycznych. Szerzej na temat kagury zob.: E. Żeromska. Maska na japońskiej scenie. Od pradziejów do powstania teatru nō. Warszawa: Wydawnictwo Trio, 2003. S. 55-100; Żeromska 2010a: 45-64.

8 Zob. przypis 1.

9 Zdaniem Zeamiego (1363-1443), głównego twórcy i teoretyka teatru nō, aktor powinien naśladować kryjącą się w głębi serca istotę rzeczy, a nie powierzchowne oznaki indywidualności danej osoby. 
pokrytą makijażem, swoją umowną, niejako „czysto teatralną" kobiecość manifestuje zwykle odpowiednim nakryciem głowy nazywanym binan boshi (dosł. czapka przystojnego mężczyzny) ${ }^{10}$.

Sławę pierwszej, publicznie występującej, realnej artystki w Japonii zdobyła dopiero kapłanka sintoistyczna Okuni ze świątyni Izumo Taisha w Izumo (Izumono Okuni; 1571?-1613), której taneczny popis w 1603 roku w Kioto został uznany za symboliczny początek mieszczańskiego teatru kabuki, znanego najpierw jako okuni kabuki (kabuki w stylu Okuni) lub onna kabuki (kobiece kabuki11). Od 1629 roku, czyli odkąd siogun Tokugawa Iemitsu (1604-1651; jako siogun 1623-1651) wprowadził bezwzględny zakaz występowania kobiet na scenie, to cieszące się wielką popularnością żeńskie widowisko przeszło w ręce wyłącznie mężczyzn, którzy zaczęli odgrywać postaci kobiece. Od tamtej pory aktor kabuki, specjalizujący się w żeńskim emploi (jap. onnagata), dąży do przedstawienia własnego wyobrażenia o ideale kobiety, do przedstawienia jej doskonalszą niż jest w rzeczywistości. W tym celu ukrywa wszystkie oznaki swej męskości: twarz - pod grubą warstwą wyrazistego makijażu, ciało - pod często bardzo strojnym kostiumem odzwierciedlającym, podobnie jak peruka, kanony rzeczywistej mody obowiązującej w danym okresie historycznym, ponadto znacznie podwyższa głos i każdemu gestowi nadaje miękkości i delikatności. Aktor kabuki, grając zatem wbrew prawom natury, wbrew własnej męskości, przekracza granice rzeczywistości i nierealności. Tworzy odrealnione, stylizowane piękno.

\section{Realizm a japońskie aktorstwo kobiece (przełom XIX i XX wieku)}

Na przełomie XIX i XX wieku okazało się, że całkowity brak aktorek w Japonii uniemożliwia stworzenie realistycznego teatru na wzór europejski, do czego wówczas zaczęto aspirować. Występująca na scenie razem z mężczyznami kobieta stała się nawet jednym z symboli teatru nowoczesnego (jap. kindai engeki). Aktorka odgrywająca (zamiast aktora) rolę żeńską zaczęła zatem oznaczać niezbędny warunek osiągnięcia efektu naturalności. Celem teatru japońskiego, teatru europeizu-

${ }^{10}$ Binan bōshi (dosł. czapka przystojnego mężczyzny) - długa biała szarfa, której środkowa część całkowicie osłania głowę, a długie, symbolizujące włosy końce są spuszczone luźno i sięgają talii.

${ }^{11}$ Nazwa teatru kabuki została utworzona na zasadzie fonetycznego i znaczeniowego podobieństwa do, pochodzącego od czasownika kabuku, rzeczownika kabuki, ale zapisywanego innym (jednym) ideogramem, który oznacza odbieganie od normy, wygłupianie się, robienie dziwnych rzeczy. Ta cecha od zarania leżała u podstaw gatunku, którego protoplaści prześcigali się w pomysłach gwarantujących zwracanie na siebie uwagi ludzi. Szerzej na temat genezy i rozwoju kabuki zob.: Żeromska 2010b: 19-36. 
jącego, miało być bowiem wierne, realistyczne odzwierciedlanie ludzkich losów, czyli inaczej niż $\mathrm{w}$ tradycyjnych gatunkach rodzimych. $\mathrm{Z}$ tego rodzaju widowiskiem Japończycy zapoznawali się wówczas po raz pierwszy w dziejach. Odkrywali jednak przy okazji, że granie postaci kobiecych przez mężczyzn nie jest specyfiką wyłącznie japońskiej czy - szerzej - dalekowschodniej tradycji, ponieważ również w Europie można znaleźć takie przykłady. W starożytności był to teatr grecki, w średniowieczu - teatr obrzędowy czy w dobie renesansu (niezależnie od aspektu sakralnego) - teatr elżbietański (szekspirowski).

W Europie aktorki zaczęły się stopniowo pojawiać na scenie w tym samym czasie, kiedy w Japonii triumfy święciła Okuni, czyli na początku XVII wieku. We Włoszech commedia dell'arte słynęła $\mathrm{z}$ angażowania aktorek. W Anglii zaczęto dopuszczać kobiety na scenę dopiero w 1656 roku, czyli dwadzieścia siedem lat po objęciu japońskich artystek zakazem udziału w publicznych występach (1629; Kawatake 127).

W Europie potrzeba angażowania kobiet do odgrywania ról kobiecych wynikła ze stopniowego upowszechniania się racjonalistycznego spojrzenia na świat, $\mathrm{z}$ wiary $\mathrm{w}$ moc rozumu, $\mathrm{w}$ rzeczywistość widzialną, doświadczalną, a nie z wiary w niewidzialne boskie moce (Kawatake 127). W starożytnej Grecji w wyniku procesu rozwoju myślenia racjonalistycznego doszło do przekształcenia $\mathrm{z}$ adresowanego do boga Dionizosa widowiska obrzędowego (bachanalia) w przedstawienie teatralne, będące formą rozrywki przygotowywanej przez człowieka dla człowieka, czyli w przedstawienie, w którym obecność kobiety na scenie stała się ważnym elementem tego rzeczywistego universum.

W Japonii, gdzie taka radykalna zmiana $\mathrm{w}$ postrzeganiu świata nastąpiła znacznie później, nie wszystkie procesy przebiegały w sposób w pełni porównywalny. Kawatake Toshio wskazuje na przykład na wyjątkowość, innej niż w teatrze europejskim, filozofii kobiecości w kabuki, gdzie (podobnie jak w $n \bar{o}$ czy kyōgen) dziedziczy się po swoim mistrzu (zwykle ojcu) nie tylko zawód aktora, ale nawet rodzaj emploi - męskie lub kobiece (Kawatake 127-128). W Europie - zdaniem Kawatake - tego rodzaju sukcesja artystyczna w ogóle nie była pożądana (Kawatake 127). Nie trzeba było przekazywać uczniowi techniki przeistaczania się $\mathrm{w}$ kobietę, ponieważ $\mathrm{w}$ opartym na słowie teatrze zachodnim $\mathrm{w}$ zupełności wystarczało powierzanie ról żeńskich wyłącznie kilkunastoletnim chłopcom o delikatnej urodzie i dziewczęcym głosie. Byli to młodzieńcy, u których nie nastąpiła jeszcze mutacja. Chłopcy ci mówili więc swym naturalnym głosem i potrzebowali właściwie tylko odpowiedniego kostiumu, aby odgrywać role żeńskie. Można zatem powiedzieć, że taka konwencja tworzenia iluzji bycia kobietą wynikała z silnej potrzeby realizmu, naturalności.

Natomiast w początkowym okresie rozwoju kabuki Okuni i inne naśladujące ją (za jej życia) artystki sprawiły, że widzowie od razu docenili urok prawdziwych kobiet na scenie i po wprowadzeniu zakazu ich występowania (1629) wywierali 
presję na aktorów onnagata, dorosłych mężczyzn, aby - wbrew własnym warunkom fizycznym i niezależnie od swojego wieku czy brzmienia głosu - odtwarzane przez nich postaci emanowały autentycznym kobiecym wdziękiem. Japończycy, w przeciwieństwie do Europejczyków, woleli zatem nierzeczywistość od rzeczywistości. W istocie oczekiwali od artystów czegoś - jakby się mogło wydawać - niemożliwego. Domagali się bowiem uprawdopodobnienia fałszu, czyli kreowania przez aktorów onnagata scenicznych postaci, które wprawdzie miałyby odzwierciedlać potrzebę nienaturalności, ale jednocześnie odznaczałyby się niezwykłym realizmem. Japońscy aktorzy odnieśli jednak sukces. Stworzyli styl, którego unikalną cechą jest realizm stylizowany. O trwałości tego sukcesu świadczyć może obecnie na przykład to, że jeden z najwybitniejszych współczesnych odtwórców kobiecych ról, Bandō Tamasaburō V (ur. 1950)12, grając zarówno w konwencji kabuki japońską księżniczkę, jak i - grając pośród aktorek - w konwencji nowoczesnego, westernizującego shingeki (dosł. nowy teatr) ${ }^{13}$ Szekspirowską Ofelię czy też Nastazję w Nastazji według Dostojewskiego w reżyserii Andrzeja Wajdy (1994), w najdrobniejszym szczególe nie zdradza swej prawdziwej męskiej natury. Jest uosobieniem doskonałej kobiecości. W teatrze zachodnim taka sytuacja wydaje się raczej nie do pomyślenia.

Japońscy aktorzy, osiągnąwszy mistrzostwo w technice przeistaczania się w kobietę i postrzegający tę umiejętność za oczywistą, przez stulecia nie odczuwali potrzeby wprowadzania zmian. Dopiero w połowie XIX wieku zaczęli uświadamiać sobie, że z perspektywy zachodniej tradycji teatralnej to, co im wydaje się naturalne, można uznawać za nierealistyczne. Nie przypuszczali też, że realizacja podjętego wkrótce po otwarciu kraju na świat postanowienia o modernizacji kabuki na wzór europejski, czego oznaką miałoby być zastąpienie onnagata aktorkami, okaże się niemożliwa ze względu na to, że byłoby to zaprzeczeniem mocno utrwalonej w tym teatrze ogólnej koncepcji stylizowanego piękna, stylizowanego realizmu. Z tego właśnie powodu kabuki (sądzę, że na szczęście dla kabuki) zdołało oprzeć się próbie czasu i stale emanuje urodą, i siłą unikalnej, męskiej tradycji kobiecości.

Niekwestionowana w dzisiejszych czasach obecność zawodowych aktorek na scenie shimpa (nowa szkoła) ${ }^{14}$ czy w pełni opartego na zachodnich wzorcach shinge$k i$ jest zatem efektem wieloletnich zmagań z rodzimą tradycją teatralną, z własnymi przyzwyczajeniami czy uprzedzeniami. Jest ponadto rezultatem ożywionej, rozpoczętej pod koniec XIX wieku dyskusji o realizmie w teatrze japońskim. Dys-

12 Bandō Tamasaburō V - jeden z najlepszych współczesnych aktorów kabuki specjalizujących się $\mathrm{w}$ rolach kobiecych

${ }^{13} \mathrm{Na}$ temat shingeki zob.: M. Melanowicz. Literatura japońska. T. 3: Poezja XX wieku. Teatr XX wieku. Warszawa: Wydawnictwo Naukowe PWN, 1996. S. 303-311.

${ }^{14}$ Na temat shinpa zob.: Melanowicz 1996: 292-297. 
kusja ta dotyczyła także terminologii, ponieważ brakowało odpowiednika słowa „aktorka”. Spory na ten temat trwały około dziesięciu lat. Ostatecznie przyjął się wyraz joy $\bar{u}$, który zastąpił chętnie wcześniej używany termin jo-yakusha (kobieta-aktor). W okresie "przejściowym”, czyli zanim w Japonii pojawiły się zawodowe aktorki, w sztukach w stylu europejskim role kobiet odgrywali specjalizujący się w rolach żeńskich aktorzy kabuki, co nie zakłócało poczucia realizmu ówczesnych widzów.

\section{Początki japońskiego aktorstwa kobiecego (przełom XIX/XX wieku)}

Rozwój japońskiego aktorstwa kobiecego nie byłby możliwy bez wysiłku mężczyzn: aktorów (głównie kabuki), reżyserów, dramatopisarzy czy teoretyków zafascynowanych teatrem zachodnim pasjonatów. To oni musieli zrezygnować $\mathrm{z}$ tradycyjnego sposobu myślenia i pogodzić się z nowymi, nieodwracalnymi tendencjami. Zanim jednak $\mathrm{w}$ pełni zaakceptowali partnerowanie aktorek i mogli powierzyć im wszystkie przeznaczone dla nich role w sztukach w stylu zachodnim, proponowali rozwiązania pośrednie.

Pierwsza kobieta, która po wielu stuleciach pojawiła się na scenie razem z mężczyznami nazywała się Chitose Beiha (1854-?). Nie była ona zawodową aktorką, ale należała do zespołu Azumaza i w 1891 roku wystąpiła z nim na deskach tokijskiego teatru Seibikan (Kawatake 126). Zagrała wówczas w sztuce Seitō bidan shukujo no misao (Cnotliwa dama, czyli wzruszające opowieści partyjne, 1891) napisanej przez krytyka i dramaturga Yodę Gakkaia (1833-1909). Producentem był Ii Yōhō (właśc. Ii Shinzaburō; 1871-1932) - od 1891 roku członek założonego przez Kawakamiego Otojirō (1864-1911) zespołu Kawakamiza wpisującego się w nurt shinpa (Rimer bp). Ii Yōhō również wystąpił w tym przedstawieniu, a z czasem zaczął być zaliczany do grona najwybitniejszych aktorów shinpa.

Występ Chitose Beihy uznano za wielki przełom, ponieważ odbył się on dwieście sześćdziesiąt dwa lata po wprowadzeniu (1629) zakazu występowania kobiet na scenie (Kawatake 126). W tym samym roku odnotowano jeszcze inne ważne wydarzenia. Przyczynił się do nich między innymi wybitny aktor kabuki, Ichikawa Danjūrō IX (1838-1903), jeden z pierwszych orędowników dopuszczania kobiet na scenę. Wykorzystując magię własnego nazwiska oraz koneksje towarzyskie, promował on kariery artystyczne swoich córek: Ichikawy Jitsuko (pseudonim artystyczny: Ichikawa Suisen I; 1881-1944) oraz Ichikawy Fukiko (pseudonim artystyczny: Ichikawa Kyokubai; lata życia nieznane; Kawatake 129). Obie artystki związały się z nurtem shinpa i debiutowały w lipcu 1891 roku. Wystąpiły wówczas w przedstawieniu złożonym z dwóch sztuk opartych na dramatach klasycznych: 
Fuji musume (Dziewczyna wistaria) ${ }^{15}$ oraz Matsukaze (Wiatr w sosnach) ${ }^{16}$. Spektakl ten, zaprezentowany na scenie teatru kabuki Shintomiza (wcześniejsza nazwa: Moritaza), miał charakter charytatywny.

W tym samym czasie zaczęto angażować kobiety do nowo powstałych zespołów teatralnych. Na przykład w listopadzie 1891 roku Ii Yōhō, w tokijskiej dzielnicy Asakusa, założył Reformatorski Teatr Mężczyzn i Kobiet (Danjo Gōdō Kairyō Engeki; Melanowicz 1994: 469) i występował na jego deskach wraz z pierwszymi japońskimi aktorkami, jak wspomniana Chitose Beiha czy Mizuno Yoshimi (1863-1928).

Do grona onnagata, którzy starali się rekompensować brak aktorek, należał na przykład podziwiany w Tokio Kataoka Gadō III (1861-1907). W lipcu 1892 roku związał się on z nurtem shinpa i pod zmienionym nazwiskiem Yamaguchi Sadao zaczął z powodzeniem występować zarówno w emploi kobiecych, jak i męskich. Podobnej wszechstronności oczekiwał również od kobiet Ichikawa Danjūrō IX (Kawatake 130). Był on jednak równocześnie przeświadczony, że ostatnią aktorką mogącą posiąść takie umiejętności była Ichikawa Kumehachi (1846-1913) - wywodząca się z tego samego co on, wielkiego rodu, znakomita, ale nigdy nie dopuszczona na profesjonalną scenę kabuki odtwórczyni ról męskich (jap. tachiyaku).

Żyjąca na pograniczu epok Ichikawa Kumehachi należała do licznego grona Japonek, które mimo zakazu dbały o rozwój własnego talentu (Kawatake 130-131) bez konieczności łączenia swej działalności z nierządem i bez utraty szacunku. Była ona bowiem jedną z ostatnich kyōgenshi, które w okresie Edo (1600-1868) uczyły wędrowne artystki tańca, a niekiedy również aktorstwa. Po otwarciu się Japonii na świat (1868) Ichikawa Kumehachi, pod pseudonimem Morizumi Gekka, przez pewien czas występowała w należącym do nurtu shinpa zespole Kawakamiza, założonym w 1896 roku przez Kawakamiego Otojirō. Kumehachi uważana jest za symbol przejścia od tradycji do nowoczesności w teatrze japońskim - symbol narodzin zawodowego aktorstwa kobiecego.

\section{Sada Yakko - pierwsza japońska aktorka zawodowa}

Kolejny etap rozwoju aktorstwa kobiecego wyznaczają Hanako (właśc. Ōta Hisa, 1868-1945; Osiński 2008a: 299) oraz słynna Sada Yakko17 (właśc. Sada Koya-

${ }^{15}$ Fuji musume (1826) - sztuka taneczna, należąca do repertuaru kabuki; taniec wyraża miłość, a jego istotą są doznania estetyczne (elegancja ruchów wykonawcy tańczącego na tle dużego drzewa wistarii; wielokrotna zmiana kostiumu na oczach widzów).

${ }_{16}$ Matsukaze - znana, poetycka sztuka nō autorstwa Zeamiego o wspomnieniu miłości opowiedzianym kapłanowi przez duchy dwóch dziewcząt o imionach Matsukaze i Murasame.

${ }^{17} \mathrm{~W}$ tekstach z przełomu XIX i XX wieku można się spotkać z błędnym zapisem Yacco. 
ma; znana też jako: Kawakami Sada, Kawakami Sadayakko, Madame Sada Yakko; 1871-1946) ${ }^{18}$.

Hanako nie była doceniana w Japonii, ale niemal na całym świecie odnosiła same sukcesy. Zachwycano się nią między innymi w Danii, Francji, Niemczech, Turcji, Anglii, Rosji, Austrii, Szwajcarii, Bułgarii, Rumunii, Polsce, Stanach Zjednoczonych. Do rozwoju jej zagranicznej kariery przyczyniła się amerykańska tancerka, Marie Louise Fuller (1862-1926).

Sława Hanako, choć trwa do dziś, między innymi dzięki portretom i rzeźbom Auguste' a Rodina (1840-1917), jest przyćmiona blaskiem talentu Sady Yakko, która w okresie od 1899 do 1902 roku, wraz z mężem, Kawakamim Otojirō, i założonym przez niego zespołem Kawakamiza, podbijała sceny Ameryki Północnej i Europy, a od 1903 roku - wyłącznie sceny w całej Japonii (Kawatake 131) ${ }^{19}$. W 1899 roku wystąpiła między innymi w San Francisco, Seattle, Waszyngtonie, Chicago, Nowym Jorku, Bostonie. Potem odwiedziła niemal wszystkie kraje europejskie. W 1900 roku prezentowała się w Londynie, w 1901 roku - w Glasgow, Paryżu, Brukseli, a w 1902 roku - w Berlinie, Rzymie, Zurychu, Wiedniu, Pradze, Budapeszcie, Bukareszcie, Lwowie, Łodzi, Krakowie, Warszawie, Sankt Petersburgu, Moskwie, Barcelonie, Madrycie, Marsylii, Antwerpii i wielu innych miastach.

Sada Yakko reprezentowała stworzony przez Kawakamiego Otojirō styl przedstawień, który został określony jako shinpa. Styl ten odznaczał się realizmem typowym dla teatru zachodniego, a jednocześnie był stale bardzo mocno zakorzeniony w postrzeganym jako "stara szkoła” (jap. kyūha) teatrze kabuki. Pod nazwą shinpa należy zatem rozumieć ruch reformujący kabuki, czyli spektakle kabuki odmienione przez wyeliminowanie $\mathrm{z}$ nich pieśni chóralnych jako integralnego elementu, przez ograniczenie roli muzyki, wprowadzenie współczesnego repertuaru, zmodernizowanie aktorstwa czy angażowanie kobiet.

Podobieństwo stylu charakterystycznego dla grupy Kawakamiza do stylu „starej szkoły" (kabuki) wynikało między innymi z tego, że w zespole tym poza Sadą Yakko nie było aktorek i role kobiece niezmiennie wykonywali mężczyźni. Również repertuar obfitował w sztuki inspirowane rodzimą tradycją literacką (dramaturgiczną), wykorzystujące dobrze znane Japończykom motywy zaczerpnięte $\mathrm{z}$ różnych utworów. Były to więc przedstawienia niejednolite pod względem stylistycznym, które, choć osadzone w tradycji kabuki, daleko wykraczały poza klasyczną konwencję tego teatru. Wielki międzynarodowy sukces zespołu Kawaka-

18 Zob.: L. Downer. Madamme Sadayakko. Gejsza, która uwiodła Zachód. Tłum. Patryk Gołębiowski. Warszawa, 2009; Z. Osiński. Polskie kontakty teatralne z orientem w XX wieku. T. 1: Kronika. Gdańsk, 2008. S. 11-17; Z. Osiński. Polskie kontakty teatralne z orientem w XX wieku. T. 2: Studia. Gdańsk, 2008. S. 21-30; E. Nowosielska. „Sada Yakko - egzotyczna ciekawostka czy trwała inspiracja dla polskiego teatru?". Japonica. Japończycy w świecie (do XX wieku). Red. E. Pałasz-Rutkowska. Warszawa: Polska Fundacja Japonistyczna, 2016. S. 216-257.

19 Por.: Osiński 2008a: 299. 
miego Otojirō był niewątpliwą zasługą nieprzeciętnie utalentowanej Sady Yakko, w swojej ojczyźnie nazywanej japońską Eleonorą Duse, porównywanej też do najsłynniejszych zachodnich aktorek tego samego pokolenia, jak Sara Bernard czy Ellen Alice Terry.

Podczas tournée zagranicznych zespół Kawakamiza prezentował zarówno współczesne adaptacje różnych tradycyjnych sztuk japońskich, jak i sztuk zachodnich. W czasie występów w Stanach Zjednoczonych Sada Yakko występowała $\mathrm{w}$ roli młodej tancerki ze sztuki tanecznej kabuki (jap. Shōsagoto) ${ }^{20}$ zatytułowanej Dōjōji (Świątynia Dōjōji) 21. W Polsce natomiast triumfowała jako bohaterka sztuk pt. Gejsza i rycerz, Bzy kwitna, Kesa, Siogun oraz fragmenty Kupca weneckiego Szekspira (Osiński 2008a: 15-16).

Sada, podobnie jak cały zespół, wszędzie była przyjmowana z wielkim entuzjazmem zagłuszającym zdecydowanie mniej liczne opinie negatywne. Jej talent podziwiali między innymi Isadora Duncan, Paul Valéry, André Gide, Henri de Toulouse-Lautrec, Claude Debussy, Pablo Picasso - autor trzech portretowych rysunków Sady Yakko, Auguste Rodin, który poprosił Sadę o pozowanie, ale został potraktowany odmownie, ponieważ ona podobno nic nie wiedziała o tym rzeźbiarzu, ponadto Stanisław Wyspiański czy Zenon Przesmycki (Miriam). W Polsce jej występy komentowano we wszystkich najważniejszych gazetach - nie zawsze całkowicie bezkrytycznie (Osiński 2008a: 15-16) ${ }^{22}$.

Sada Yakko i wszyscy towarzyszący jej aktorzy byli pierwszymi japońskimi artystami scenicznymi, którzy wystąpili za granicą. Dzięki nim po raz pierwszy w dziejach widzowie amerykańscy i europejscy, podobnie jak chińscy i koreańscy, mogli się zapoznać z teatrem japońskim, postrzeganym przez nich jako bardzo egzotyczny i w związku z tym tradycyjny. Oszołomieni odmiennością, nie mając możliwości porównania pokazów, które oglądali, z rozwijającym się od początku XVII wieku właściwym teatrem kabuki, nie potrafili rozpoznać, że prezentowane spektakle, choć tematyką czy techniką gry oraz tańca jedynie nawiązywały do klasycznych wzorców (głównie kabuki), w rzeczywistości nie tylko były - z chęci upodobnienia do sztuk Szekspira - skrócone i uproszczone przez Kawakamiego Otojirō, ale jednocześnie utrzymane $\mathrm{w}$ konwencji teatru zachodniego i $\mathrm{z}$ tego powodu w Japonii nie spotykały się z pozytywnym przyjęciem (Kawatake 133).

O typowym niezrozumieniu i wynikających z niego kłopotach ówczesnych Europejczyków z interpretacją tego, co oglądali mogą świadczyć na przykład dwa

${ }^{20}$ Sztuki kabuki dzielą się na: historyczne (jap. jidaimono), obyczajowe (jap. sewamono) i taneczne. Por. przypis 13.

${ }^{21}$ Dōjōji - sztuka kabuki będąca adaptacją (tak samo zatytułowanej) sztuki nō o młodej kobiecie obsesyjnie zakochanej w mnichu buddyjskim ze świątyni Dōjōji.

$22 \mathrm{~W}$ niniejszym artykule posłużono się zaledwie sygnalnymi przykładami takich opinii. Świadomie pominięto też wymagającą odrębnych studiów ważną kwestię wpływu Sady Yakko na rozwój polskiego modernizmu, o czym można przeczytać w: Nowosielska. 
artykuły polskiego dziennikarza i krytyka teatralnego (również literackiego i muzycznego), Witolda Noskowskiego, który kilka razy miał okazję widzieć w Europie występy Sady Yakko i Kawakamiego Otojirō, a dopiero po blisko trzydziestu latach pierwszy raz zobaczył - jak prawdopodobnie również błędnie sądził przedstawienie kabuki. Jeden artykuł, opublikowany 6 lutego 1931 roku w „Kurierze Poznańskim”, jest zapowiedzią występu, który miał się odbyć w warszawskim Teatrze Wielkim, a drugi, mający charakter recenzji z tego spektaklu, ukazał się w poznańskim tygodniku „Tęcza” 23 .

1.

Trzydzieści lat minęło od objazdu Europy przez pełną wdzięku Sadę Yacco ${ }^{24}$, ćwierć wieku od takiejże podróży panny czy pani Hanako. Michio Itōo ${ }^{25}$, dyrektor wielkiej sceny tokijskiej, przeprawił teraz swoich aktorów przez Pacyfik do Północnej Ameryki, gdzie odbyli wielkie tournée, i trupa ta powraca do Japonii przez Europę. Przejechała ją od Rzymu i Sztokholmu via Paryż i Berlin, teraz bawi w Warszawie i zjeżdża do naszego Teatru Wielkiego [...] (cyt. za: Osiński 2008b: 25-26) ${ }^{26}$. Na czele jej stoi Tokudżiro Tsui-tsui ${ }^{27}$, znakomity artysta i reżyser. [...]

Pan Tokudżiro Tsui-tsui jest wyjątkiem wśród aktorów japońskich do pewnego stopnia. Nie pochodzi bowiem z rodziny aktorskiej, podczas gdy zwyczajnie artyści sceniczni idą po sobie pokoleniami. Jako syn handlarza starożytności nie myślał zrazu o teatrze, podczas wojny rosyjsko-japońskiej ${ }^{28}$ był sobie artylerzystą, potem dopiero wstąpił na scenę, ale zdobył wielkie imię między aktorami japońskimi. Jeszcze bardziej odstępuje trupa jego od tradycji tym, że role kobiece grają kobiety, nie mężczyźni. [...]

Tokudżiro Tsui-tsui grywa kilka sztuk. U nas przedstawi liryczny dramat z tańcami Koi-no-yozakura (podany w programie polski tytuł Miłość w porze kwiatu wiśni krytyk zmienia na Miłość podczas kwitnienia wiśni), dalej Kage-no-chikara, czyli Drzemiąca opatrzność ${ }^{29}$, wreszcie Mitsuhide, dramat historyczny na tle dziejów wieku XVI (Mitsuhide jest nazwiskiem bohatera). Między tymi utworami zaprezentują aktorzy japońscy tańce, mianowicie "taniec lisi”, który wykona Tokudżiro Tsui-tsui, taniec maskowy (taniec z maską) oraz taniec ludowy. (Osiński 2008b: 25-26) ${ }^{30}$

${ }^{23} \mathrm{~W}$ źródle cytatu nie podano szczegółowych danych dotyczących numeru czasopisma z tą recenzją.

24 Zob. przypis 15.

${ }^{25}$ Michio Itō (1892-1961) - wybitny japoński tancerz i choreograf; współpracował z wieloma wybitymi literatami i artystami, jak m.in. z Williamem Butlerem Yeatsem (1865-1939), Ezrą Poundem (1885-1972), Marthą Graham (1894-1991).

${ }^{26}$ Oryginalny artykuł: „Teatr Japoński w Poznaniu” Kurier Poznański 58 (6 II 1931). S. 11.

27 Prawidłowy zapis tego nazwiska (stosowany w niniejszym artykule w każdym wypadku poza przytoczonymi cytatami W. Noskowskiego) powinien być następujący: Tsutsui Tokujirō.

${ }_{28}$ Wojna rosyjsko-japońska była prowadzona w latach 1904-1905.

29 Dosłowne tłumaczenie tego tytułu powinno brzmieć Siła cienia.

${ }^{30} \mathrm{~W}$ pierwszym tomie książki Kronika jest podany kompletny program tego przedstawienia, ponadto nazwiska wykonawców oraz wykaz publikacji na temat tournée po Polsce zespołu Tsutsuia 
2.

Teatr japoński, który pod dyrekcją Tokudżira Tsui-tsui objeżdża Europę i zawadził o Poznań oraz o Warszawę, jest pierwszą od ćwierć wieku wycieczką sztuki japońskiej poza ojczyznę. Na wystawę paryską roku 1900 przybyła Sada Yacco z mężem swoim, świetnym tragikiem Kawakamim, i przez następne dwa lata krążyła po kontynencie. Za jej śladem zjawiła się również milutka, ale gorzej grająca Hanako. Dzisiaj zapewniają nas, że ani jedna, ani druga nie uchodziły w swojej ojczyźnie za wielkie aktorki stylu japońskiego nie reprezentowały, natomiast trupa Tokudżira Tsui-tsui jest wzorem tradycji starej kultury. Być może. Dla nas te odcienie są nieuchwytne. Widziałem kilkakrotnie teatr Sady Yacco, w lecie roku ubiegłego natknąłem się w Sztokholmie na trupę Tokudżiro Tsui-tsui i sięgnąwszy do wspomnień, różnicy nie potrafiłbym sobie uświadomić. Natomiast podobieństwo wydaje się zupełne.

Polega ono zarówno na repertuarze, jak na kulturze aktorskiej. Tokudżiro Tsui-tsui tytułuje swoje przedstawienia "teatrem kabuki”, dodając, że nazwa ta oznacza teatr wieku XVIII, który czerpie swoje tematy z japońskich czasów feudalnych, a to z XVII i nawet z XVI stulecia. Podobnych rycerzy (samurajów, książąt, dajmjów ${ }^{31}$ ) i ich orszaki widywaliśmy u Sady Yacco i w podobnych konfliktach, które nam, wychowanym w innej etyce [...] często bywają niedostępne, a przynajmniej trudno zrozumiałe, chociaż ich wielkość moralna jest niewątpliwa [...].

Summa summarum: teatr niezwykłej doskonałości, rezultat długich lat pacy bardzo świadomej i technicznie doprowadzonej do mistrzostwa. Wrażenie nie tylko egzotyki, ale wstrząsającej ekspresji uczuć za pomocą głosu i wyrazu ciała. Warto to było widzieć. (Osiński 2008b: 26-28) ${ }^{32}$

Z przedstawionego przez Witolda Noskowskiego opisu programu warszawskiego spektaklu nie wynika wprawdzie jednoznacznie, że były to sztuki kabuki, ale uwagę zwraca szereg nieścisłości. Przede wszystkim Tsutsui Tokujirō ( 18811953) nie był aktorem kabuki, a do jego zespołu należały kobiety. Ponadto fragmenty sztuk zaprezentowanych w Polsce były jedynie własnymi, dokonanymi przez Tsutsuia adaptacjami odpowiednich fragmentów dramatów kabuki i w związku z tym jest wielce prawdopodobne, że nie zostały one wykonane przez aktorów z użyciem innych niż ściśle określone przez tradycję kabuki środków. Poza tym bardzo popularny w Japonii taniec lisa (najprawdopodobniej kitsune mai lub kitsune odori) może wprawdzie pochodzić z jakiejś sztuki kabuki, której jest elementem, ale równie dobrze mógł to być taniec ludowy, bądź wpisany w inną japońską tradycję widowiskową, niekoniecznie teatralną. Określenie Noskowskiego „taniec

Tokujirō (7-22 lutego 1931 roku; w sumie 18 spektakli w Warszawie, Poznaniu, Łodzi, Krakowie i we Lwowie). Zob.: Osiński 2008a: 33-37.

${ }^{31}$ Chodzi o książąt feudalnych daimyō.

32 Oryginalny artykuł: W. Noskowski. „Życie teatralne. Przyjechali Japończycy - Od Sady Yacco do Tokudżira Tsu-tsui. Teatr kabuki - „Drzemiąca opatrzność” - Jak na drzeworytach - Wielka sztuka o wielkiej tradycji". Tęcza z. 9 (28 II 1931). S. 18. Przedruki wielu innych recenzji z tego przedstawienia znajdują się w Osiński 2008b: 123-146. 
maskowy” czy "taniec z maską" również wyklucza przynależność tego tańca do tradycji kabuki. Stwierdzenie, że „zawodowy tancerz, Hajime Mori, zmieniał kilkakrotnie maskę i do niej dostrajał taniec" (Osiński 2008b: 127) ${ }^{33}$, nie przystaje ani do konwencji teatru nō, którego - można powiedzieć - istotą jest maska (w obrębie jednej sztuki zmieniana maksymalnie jeden raz), ani do konwencji kabuki, ponieważ aktorzy (tancerze) tego teatru nie występują w maskach. $\mathrm{Z}$ tego powodu wydają się oczywiste trudności Noskowskiego z określeniem wyraźnych różnic między stylem prezentowanym przez Sadę Yakko i Kawakamiego Otojirō a stylem przedstawień zaprezentowanych przez zespół Tsutsuia Tokujirō. Najprawdopodobniej tylko intuicja sprawiła, że Noskowski nie dał się zwieść zapewnieniom Tsutsuia Tokujirō o tym, że jego zespół reprezentuje właściwy teatr kabuki. Trudno dziś dociec, jakie intencje przyświecały temu japońskiemu artyście.

Poczucie bezradności i rozżalenia z powodu braku wiedzy i nieumiejętności właściwej oceny występów japońskich zespołów wyraźnie przebija z tonu, opublikowanej w 1931 roku w „Kurierze Lwowskim”, recenzji znawcy teatru elżbietańskiego, Władysława Tarnawskiego, który z kolei - również najwyraźniej nieświadomie - niesłusznie zarzuca Sadzie Yakko, że celowo doprowadziła do następującej sytuacji:

Niełatwa to rzecz Europejczykowi pisać o przedstawieniu japońskim. Na każdym kroku czyhają pułapki. Gdy przed laty z górą dwudziestu objeżdżała naszą część świata Sada Yakko, recenzenci teatralni zachwycali się jej teatrem jako typową próbką sztuki scenicznej jej ojczyzny. Tymczasem w ojczyźnie zbierał on pochwały jako europejski... Sprytna i wybitnie zdolna gejsza stworzyła własny genre, łączący żywioły rodzime z obcymi, i zdołała wywieść w pole obie strony, z którymi miała do czynienia. (Osiński 2008b: 124$)^{34}$

$\mathrm{Z}$ „edukacyjnego" qui pro quo wynikły jednak niewątpliwie obustronne korzyści polegające na stopniowym poznawaniu się i na wzajemnych inspiracjach. W rysunkach, obrazach, rzeźbach, dramatach, kompozycjach muzycznych europejskich artystów, zaintrygowanych subtelnym urokiem japońskiej estetyki, zaczęły być stopniowo coraz częściej widoczne ślady tej fascynacji. Minie jeszcze wiele lat zanim zrozumienie i właściwa ocena okaże się możliwa.

Tymczasem w rzeczywistości ani Sada Yakko, ani Kawakami Otojirō, wyjeżdżając z Japonii, niewiele wiedzieli o Zachodzie - i jego historii, kodzie obyczajowym i kulturowym. Nie znali nazwisk wybitnych amerykańskich czy europejskich artystów, którzy przychodzili ich podziwiać. Dzięki jednak kilku długoterminowym tournée, Sada i Kawakami, jako pierwsi japońscy aktorzy, mieli możliwość obejrzenia

33 Oryginalny artykuł: „Teatr w ojczyźnie gejsz. Przed premierą w Warszawie”. Światowid 6 (7 II 1931). S. 12-13.

${ }^{34}$ Oryginalny artykuł: W. Tarnawski. "Z Teatru Wielkiego. Japonia we Lwowie”. Kurier Lwowski (23 II 1931). S. 7 
wielu znakomitych przedstawień teatralnych we wszystkich krajach, w których występowali. Podpatrywali aktorów, reżyserów, poznawali kanon europejskiej literatury dramatycznej. Jednym z ważniejszych odkryć, jakich dokonali, było spostrzeżenie, że role kobiece mogą czy wręcz powinny być grane przez kobiety. To doświadczenie wywarło istotny wpływ na dalszą działalność zespołu po powrocie na stałe do Japonii. Kawakami z czasem zaczął włączać do repertuaru swojego teatru sztuki Williama Szekspira, Maurice'a Maeterlincka (1862-1949), Henrika Ibsena (1828-1906). Wystawił między innymi Kupca weneckiego ${ }^{35}$, którego widział w Bostonie podczas swego pierwszego tournée zagranicznego, ponadto Otella i Hamleta.

We wszystkich tych cieszących się powodzeniem spektaklach występowała Sada Yakko, która jednocześnie wiele czasu poświęciła kształceniu zawodowych aktorek. Uczyła ich, jak grać w sztukach w stylu zachodnim. Działalność edukacyjną prowadziła w założonym przez siebie w 1908 roku Cesarskim Instytucie Aktorek (Teikoku Joyū Giseisho), który z czasem przekształciła w Szkołę Aktorstwa przy Teatrze Cesarskim (Teikoku Gekijō Fuzoku Gigei Gakkō), popularnie nazywaną Cesarską Szkołą Aktorek (Teikoku Jōyū Gakkō). Tam kształciły się pierwsze japońskie aktorki zawodowe, wywodzące się z różnych środowisk społecznych, jak na przykład Mori Ritsuko (1890-1961), Murata Kakuko (1893-1969) czy Hase Namiko (lata życia nieznane) i wiele innych. W 1924 roku, po śmierci Kawakamiego, Sada Yakko założyła też Dziecięcy Zespół Kawakamiego (Kawakami Jidō Gekidan) oraz Teatr Muzyczny (Ongaku Gekijō; Kawatake 133).

Kawakami Otojirō i Sada Yakko (a wcześniej również Chitose Beiha) swoją naznaczoną pasmem sukcesów działalnością przyczyniali się do wzrostu zainteresowania teatrem zachodnim i wiedzy o nim, a przede wszystkim inicjowali wielką reformę teatru japońskiego i wyznaczyli nowe kierunki jego rozwoju. Okazali się zwiastunami nurtu shingeki, w którym zawodowa aktorka stała się warunkiem sine qua non. Mimo to nawet obecnie nikogo w Japonii nie dziwi, że scena może należeć wyłącznie do mężczyzn lub wyłącznie do kobiet ${ }^{36}$.

\section{Shingeki}

Problem dopuszczania aktorek na scenę w istotny sposób dotyczył też nurtu shingeki, za którego umowny początek uważa się rok premiery (1909) sztuki Jan

35 Obecnie Kupiec wenecki znany jest w Japonii pod dosłownie przetłumaczonym tytułem Benisu no shōonin, ale autor pierwszego tłumaczenia (1883) tej sztuki Szekspira, Inoue Tsutomu (1850-1928), opublikował ją i spopularyzował pod tytułem Jinniku hitojichi saiban (Zakład o funt ludzkiego ciała). Zob. Kawatake 132-133.

36 Przykładem teatru, w którym występują wyłącznie kobiety jest założony w 1913 roku rewiowy zespół Takarazuka (Takarazuka Kagekidan) mający swoją główną siedzibę w Osace. W teatrze tym role męskie wykonywane są przez kobiety. 
Gabriel Borkman Ibsena, wystawionej przez zespół Wolny Teatr (Jiyū Gekijō) założony przez Osanaia Kaoru (1881-1928) i Ichikawę Sadanjiego II (1880-1940).

Mimo intensywnej działalności zwolenników modernizowania teatru japońskiego na wzór zachodni, w Japonii stale brakowało zawodowych artystek scenicznych. Dlatego jeszcze kilka lat po utworzeniu Cesarskiego Instytutu Aktorek w sztukach shingeki nadal występowali głównie mężczyźni. Był wśród nich między innymi specjalizujący się w rolach kobiecych aktor kabuki Ichikawa Sadanji II, byli też Doi Shunsho (1869-1915) ${ }^{37}$ czy Minaguchi Byō (1873-1940) 38 .

O narodzinach właściwego teatru w stylu zachodnim zaczęto mówić dopiero wówczas, gdy w 1911 roku Matsui Sumako (1886-1919; Kawatake 133; Melanowicz 1996: 303-305; Tubielewicz 82) zasłynęła jako Ofelia z Hamleta Szekspira oraz jako Nora z Domu lalki Henrika Ibsena. Obie sztuki były w inscenizacji Towarzystwa Literackiego (Bungei Kyōkai ${ }^{39}$ ), które dwa lata później rozpadło się z powodu skandalu obyczajowego wywołanego przez tę wybitnie utalentowaną aktorkę. Związała się ona bowiem prywatnie z żonatym Shimamurą Hōgetsu (1871-1918), członkiem Towarzystwa, pisarzem, literatem, wpływowym reformatorem teatru japońskiego, fundatorem zespołu Geijutsuza (Teatr Artystyczny) ${ }^{40}$.

Trupa Shimamury wpisywała się w nurt shingeki. Z powodzeniem wystawiała sztuki zachodnich dramatopisarzy: Henrika Ibsena, Maurice'a Maeterlincka, Lwa Tołstoja (1828-1910). Główne role kobiece odgrywała współtwórczyni i największa gwiazda teatru Geijutsuza, Matsui Sumako, która jak Sada Yakko przyciągała widzów w Japonii oraz podczas występów poza jej granicami - w Korei, Mandżurii, Rosji, na Tajwanie. Z czasem aspiracje finansowe zaczęły przesłaniać względy artystyczne (Kawatake 133).

Zespół Geijutsuza działał zaledwie sześć lat (1913-1919). Został rozwiązany po śmierci Shimamury. Zrozpaczona po stracie partnera życiowego i zawodowego Matsui Sumako popełniła samobójstwo. Miała zaledwie trzydzieści trzy lata. Mimo młodego wieku stała się legendą shingeki. Wielkość talentu i tragiczny los sprawił, że po kilku dziesięcioleciach Matsui Sumako zaczęła być kojarzona z amerykańską aktorką - otrzymała przydomek japońskiej Marilyn Monroe (Melanowicz 1996: 305; Tubielewicz 193-194).

37 Wcielił się w rolę Portii z Kupca weneckiego Szekspira, wystawionego przez Bungei Kyōkai (Towarzystwo Literackie). Zob. Kawatake 133.

${ }^{38}$ Zagrał rolę Gertrudy w Hamlecie (obok aktorki Itō Umeko odgrywającej damę dworu). Zob. Kawatake 133.

39 Bungei Kyōkai zostało założone w 1909 roku przez Tsubouchiego Shōyō (1859-1935) - pierwszego tłumacza dzieł Szekspira na język japoński.

40 Po rozwiązaniu Bungei Kyōkai, poza Geijutsuza, powstały jeszcze dwa zespoły: Butai Kyōkai (Towarzystwo Sceny) i Mumeikai (Towarzystwo Bezimiennych). Melanowicz 1994: 304. 


\section{Podsumowanie}

Sława Chitose Beiki, Sady Yakko i Matsui Sumako przetrwała do dziś. Artystki te są symbolem epokowych zmian, jakie na przełomie XIX i XX wieku zachodziły $\mathrm{w}$ teatrze japońskim. Każda $\mathrm{z}$ artystek miała udział $\mathrm{w}$ torowaniu drogi importowanym $\mathrm{z}$ Zachodu stylom i tendencjom całkowicie oderwanym od rodzimej tradycji widowiskowej, nurtom odznaczającym się niemal lustrzanym odzwierciedleniem rzeczywistości. Urealniły bycie kobietą i mężczyzną na scenie shingeki sprawiły, że mężczyzna (aktor) może pozostać mężczyzną.

Prywatnie aktorki te kreowały wzór nowoczesnej, wyemancypowanej kobiety. Dzięki nim rozwój kobiecego aktorstwa był stopniowym procesem współgrającym z postępującą modernizacją i westernizacją kultury japońskiej, japońskiego teatru.

\section{BIBLIOGRAFIA}

Downer, Lesley. Madamme Sadayakko. Gejsza, która uwiodła Zachód, tłum. Patryk Gołębiowski. Warszawa: Świat Książki, 2009.

Kawatake, Toshio. Kindai engeki-no hatten (Rozwój teatru nowożytnego), [w:] Shin NHK Shimin Daigaku Sōsho (Nowa seria NHK i Uniwersytetu Shimin) nr 11. Tōkyō: Nihon Hōsō Shuppan Kyōkai, 1982.

Kojiki, czyli Księga dawnych wydarzeń. T. 1-2, Tłum. i przypisy Wiesław Kotański. Warszawa: Państwowy Instytut Wydawniczy, 1986.

Melanowicz, Mikołaj. Literatura japońska. T. 2: Proza XX wieku. Warszawa: Wydawnictwo Naukowe PWN, 1994.

Melanowicz, Mikołaj. Literatura japońska. T. 3: Poezja XX wieku. Teatr XX wieku. Warszawa: Wydawnictwo Naukowe PWN, 1996.

Melanowicz, Mikołaj. Historia literatury japońskiej. Warszawa: Wydawnictwo Naukowe PWN, 2011.

Nowosielska, Elżbieta. „Sada Yakko - egzotyczna ciekawostka czy trwała inspiracja dla polskiego teatru?". Japonica. Japończycy w świecie (do XX wieku). Red. E. Pałasz-Rutkowska. Warszawa: Polska Fundacja Japonistyczna, 2016. S. 216-257.

Noskowski, Witold. „Życie teatralne. Przyjechali Japończycy - Od Sady Yacco do Tokudżira Tsu-tsui. Teatr kabuki - „Drzemiąca opatrzność” - Jak na drzeworytach - Wielka sztuka o wielkiej tradycji”. Tęcza z. 9 (28 II 1931). S. [18].

Osiński, Zbigniew. Polskie kontakty teatralne z orientem w XX wieku. T. 1: Kronika, Gdańsk: słowo/obraz terytoria, 2008a.

Osiński, Zbigniew. Polskie kontakty teatralne z orientem w XX wieku. T. 2: Studia, Gdańsk: słowo/obraz terytoria, 2008b.

Rimer J. Thomas, Mori, Mitsuya, Poulton M. Cody (red.). The Columbia Anthology of Modern Japanese Drama. New York: Columbia University Press, 2014.

Rodowicz, Jadwiga M. Boski dwumian. Wrocław: Instytut im. Jerzego Grotowskiego, 2009.

Tarnawski, Władysław. „Z Teatru Wielkiego. Japonia we Lwowie”. Kurier Lwowski (23 II 1931). S. 7.

„Teatr Japoński w Poznaniu” Kurier Poznański 58 (6 II 1931). S. 11.

„Teatr w ojczyźnie gejsz. Przed premierą w Warszawie”. Światowid 6 (7 II 1931). S. 12-13.

Tubielewicz, Jolanta. Kultura Japonii. Stownik. Warszawa: Wydawnictwa Szkolne i Pedagogiczne, 1996. 
Żeromska, Estera. Maska na japońskiej scenie. Od pradziejów do powstania teatru nō. Warszawa: Wydawnictwo Trio, 2003.

Żeromska, Estera. Japoński teatr klasyczny. Korzenie i metamorfozy. T. 1: Nō, kyōgen. Warszawa: Wydawnictwo Trio, 2010a.

Żeromska, Estera. Japoński teatr klasyczny. Korzenie i metamorfozy. T. 2: Kabuki, bunraku. Warszawa: Wydawnictwo Trio, 2010b. 
